\title{
Corrosion Behavior of Welded Joints in Different Stainless Steels
}

\author{
ENIKO REKA FABIAN, JANOS KUTI, JOZSEF GATI, LASZLO TOTH* \\ Obuda University, Donat Banki Faculty of Mechanical and Safety Engineering 1081 Budapest, Nepszinhaz str. 8
}

\begin{abstract}
The welded metals characteristics produced by TIG welding or laser beam welding depend on heat input as a function of laser power and welding speed. High laser power and high welding speed have produced welded joint with a remarkable decrease in fusion zone size and an acceptable weld profile with high weld depth/width ratio. At duplex stainless steels the microstructure of welded metal, and heat affected zone is strongly influenced by cooling rate, which is depend on heat input as a function of laser power and/or welding speed. It was found that increasing welding speed the corrosion rate of welded joints decreased. In austenitic stainless steels appeared pitting corrosion in the base material as well as in the welding zone. In case of 2304 duplex stainless steel pitting corrosion appeared in welded metal and heat affected zone in case of autogenously welding, but at 2404 duplex stainless steel pitting appear more in the heat affected zone.
\end{abstract}

Keywords: duplex, austenitic stainless steel, TIG, laser welding

\section{Introduction}

Due to its properties, stainless steels are becoming attractive materials for industrial applications such as steam generation, automotive, biomedical, chemical, transportation, nuclear and aerospace industries [1]. Stainless steels can be classified into different groups based on their microstructure. The most commonly used are austenite, ferrite and ferrite-austenite (duplex) groups. Duplex stainless steel has a microstructure in which the $\delta$-ferrite and austenitic $(\gamma)$ phases are evenly distributed over conventional duplex steels and 60/40 for poor duplex steels. The austenitic steel group includes the most common stainless-steel chromium-nickel steels. General purpose materials that have good resistance to atmospheric corrosion and many organic and inorganic chemicals. Suitable for processing, storing and transporting food and beverages. This makes them suitable for various applications due to their good formability and wide range of functional and aesthetic surfaces [2-3].

The ferritic-austenitic stainless-steel group, also called duplex stainless steel, combines many of the beneficial properties of ferritic and austenitic steels. Due to their high content of chromium and nitrogen, and often molybdenum, these steels have good resistance to local and even corrosion. Duplex stainless steels have excellent mechanical properties, machinability and corrosion resistance. Ferrite is high-strength and resistant to stress corrosion cracking, while austenite contributes to both good elasticity and general corrosion resistance [3-14]. Welding can degrade the optimum microstructure of duplex stainless steels [15-18], thus impairing the strength and corrosion resistance of the welded metal (VM) and heat-affected zone (HAZ) [19-21]. All duplex stainless steel solidifies as primary ferritic solidification and austenite is formed by solid state conversion. When the temperature falls below the temperature of the ferrite solvate, the ferrite is converted to austenite. This transformation ultimately determines the ferrite-austenite balance in the final weld metal. The nature of the ferriteaustenite conversion depends on the composition of the steel.

In a general definition, corrosion is a process of deterioration of a material by electrochemical or chemical associated or not to mechanical stress. Although the physical alteration of other materials may be considered by some authors as corrosion, are metals and alloys the most targeted materials in

*email: toth.laszlo@bgk.uni-obuda.hu 
this study area. Outgoing of a country with the structures that suffered corrosion, according to the "Institute of Corrosion in the UK revolve around 3.5\% of GDP [22].

Among the types of corrosion that can occur in a metal, pitting process is one of the most aggressive. This is detected as small dots on the metal surface which generally have greater depth than its diameter. If the passive layer is weak or locally damaged, and the small area not protected by the passive film becomes an anode, pitting corrosion can occur. Because this anode area is very small compared to the large cathode area of the undamaged passive film, the corrosion rate is high and a pit is formed. After initialization the $p \mathrm{H}$ in the pit will be lower than in the surrounding environment due to hydrolysis of dissolved metal ions such as $\mathrm{Fe}^{2+}$ and $\mathrm{Cr}^{3+}$. In addition, the chloride concentration in the pit increases as chloride ions migrate into the pit to compensate for the positive charge of the metal ions. Thus, pit conditions gradually become more aggressive and reproduction can continue at high speed [23]

Pitting corrosion is most common when chloride ions cause local degradation of the passive layer. The presence of halides, such as chlorides, in neutral or acidic solutions increases the corrosion capacity of both organic and inorganic acids. The solution becomes more aggressive at high chloride concentrations, low $p \mathrm{H}$ and high temperatures, but can also affect the corrosion resistance of stainless steels even with small amounts of chloride [24-26]. The pits are often small on the surface, but may have large volume inside of the metal.

\section{Materials and methods}

There were welded three different types of stainless steel with tungsten inert gas welding (TIG) and laser beam welding method. Two of the materials used were duplex stainless steel (2CrNiMnMo CuN24-4-3-2, X2CrNiN23-4; notified by Outokumpu Stainless AB as 2404 and 2304) and one austenitic stainless steel (X5CrNi18-10, notified by AISI 304). There were also studied the corrosion resistance of heterogeneous joints of duplex and austenitic steels.

Three homogenous square butt joints were studied with parent materials: 304, 2304, 2404 and one heterogeneous 304-2404 joint according to the Table 1. E309L type of wire was used for the duplex parent materials and heterogeneous welds and E308L for austenitic joint. As shielding gas was used argon, with 6 1/min flow rate.

Table 1. Parameters of tungsten inert gas welding process

\begin{tabular}{|c|c|c|c|c|}
\hline Sample & $\begin{array}{c}\text { Current } \\
(\boldsymbol{A})\end{array}$ & $\begin{array}{c}\boldsymbol{v} \\
{[\mathbf{m m} / \mathbf{s}]}\end{array}$ & Plate 1 & Plate 2 \\
\hline T 1 & 75 & 1,46 & 2304 & 2304 \\
\hline T 2 & 75 & 1,46 & 2404 & 2404 \\
\hline T 3 & 90 & 3,33 & 304 & 304 \\
\hline T 4 & 85 & 1,46 & 304 & 2404 \\
\hline
\end{tabular}

Table 2. Laser welding parameter process

\begin{tabular}{|c|c|c|c|c|}
\hline Sample & Parent materials & $\mathbf{P}[\mathbf{W}]$ & $\mathbf{v}[\mathbf{m m} / \mathbf{s}]$ & $\mathbf{f}[\mathbf{k H z}]$ \\
\hline L1 & 2304 & 5200 & 8000 & $\mathrm{CW}$ \\
\hline L2 & 2304 & 3800 & 5000 & $\mathrm{CW}$ \\
\hline L3 & 2304 & 2000 & 2000 & 50 \\
\hline L4 & 2404 & 5200 & 6000 & $\mathrm{CW}$ \\
\hline L5 & 2404 & 3800 & 7000 & CW \\
\hline L6 & 2404 & 2000 & 3000 & 50 \\
\hline L7 & 304 & 5200 & 8000 & CW \\
\hline L8 & 304 & 3800 & 5500 & CW \\
\hline L9 & 304 & 52000 & 2500 & 50 \\
\hline L10 & $2404-304$ & 3800 & 7000 & CW \\
\hline L11 & $2404-304$ & 2000 & 6250 & CW \\
\hline L12 & $2404-304$ & 2750 & 50 \\
\hline
\end{tabular}


To study the laser power effect on welded structure Trump TLF 5000 Turbo type $\mathrm{CO}_{2}$ laser welding equipment was used for laser welding (Figure 1a). There were no additional materials used. To study the effects of additional materials laser beam welded structure and on corrosion resistance welding were performed with a $2.5 \mathrm{~kW}$ Rofin DY027 diode pumped Nd:YAG laser on milled edges in butt joints without gap (Figure 1.b)-d)). The applied laser power was 2500W. High nickel content iron based metal powder (Metco41C from Sulzer Metco) and a conventional used wire for duplex stainless steels $2293 \mathrm{NL}$ with $0.8 \mathrm{~mm}$ diameter were used as additional material. The powder feeding was performed applying the self-feeding Sultzer Metco apparatus (Figure $1 \mathrm{c}$, d). With this apparatus it could be realized $15 \mathrm{~g} / \mathrm{min}$ powder addition.

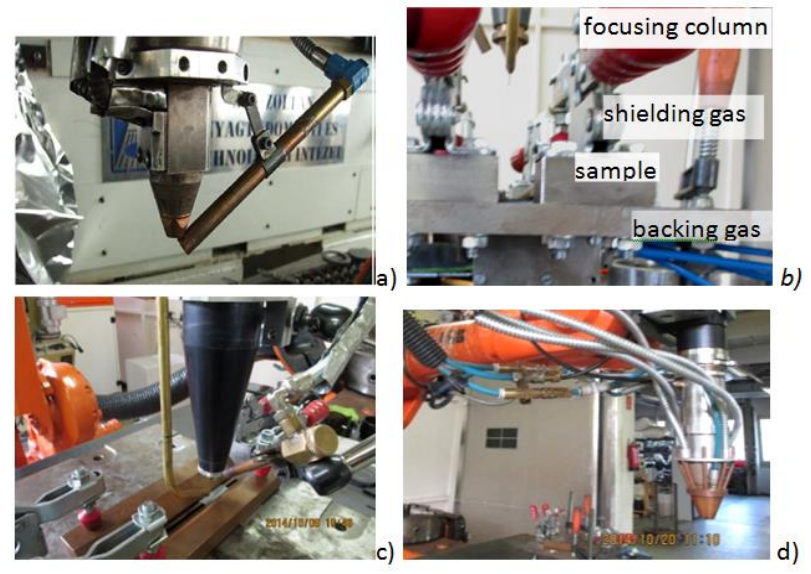

Figure 1. Installation for this work:

a)Trump TLF 5000 Turbo type $\mathrm{CO}_{2}$ Laser welding

Equipment b) arrangement of the experiment

c) wire position in front of laser beam at

Rofin DY027 diode pumped Nd:YAG laser

d) head of powder additioner concentric with laser

power column in Rofin DY027 diode pumped Nd:YAG laser

To study the microstructure of welded joints ant theirs heat affected zones (henceforth HAZ) transverse sections of the welds were metallographic prepared and etched with different etching materials.

The metallographic preparation involved cutting transverse sections on the seams, followed by grinding and polishing to $0.05 \mu \mathrm{m}$ alumina powder. The microstructures of the various regions of the welds were characterized by conventional metallographic techniques using suitable sutures for the regions. The Kalling'2 reagent consists of $100 \mathrm{~mL}$ of ethyl alcohol, $100 \mathrm{~mL}$ of hydrochloric acid and 5 mg of copper chloride, attacking ferrite and slightly attacking austenite. The various welding zones of austenitic steel can be well examined for 1-2 minutes after etching with Kalling'2 reagent. Beraha-type etching for duplex stainless steels contains a fresh mixture of $85 \mathrm{~mL}$ of water, $15 \mathrm{ml}$ of hydrochloric acid and $1 \mathrm{~g}$ of $\mathrm{K}_{2} \mathrm{~S}_{2} \mathrm{O}_{5}$. It is used by immersion until the surface is colored. Ferrite colors, but not austenite. Beraha reagent was used for quantitative analysis of microstructure consistency as it provides a sufficiently high contrast between ferrite and austenite. Microstructure and phases of welding zones were analyzed by optical microscope and SEM

To study of microstructure and the corrosion resistance of welded samples $10 \mathrm{mmx} 20 \mathrm{~mm}$ small samples were cut out from the streams and its heat affected zones and some basics materials such from TIG welded as from laser welded samples.

For testing the corrosion resistance of seams, the samples were placed in separate vials containing $100 \mathrm{~g}$ of ferric chloride hexahydrate $\left(\mathrm{FeCl}_{3} 6 \mathrm{H}_{2} \mathrm{O}\right)$ in $900 \mathrm{~mL}$ of distilled water according to ASTM G48. This test method describes laboratory tests for comparing the resistance of stainless steels and related alloys to the initiation of corrosion in recesses and crevices. The results can be used to rank 
alloys in order to increase the scoring and corrosion resistance of the gaps under the specific conditions of these methods. The test was performed for a total of 72 hours and the changes by the samples were monitored after 24-, 48- and 72 hours intervals. During the experimental period, weight change was measured and surfaces of samples were studied by SZX16 stereo microscope.

The electrochemical measurements were performed on an Im6eX electrochemical workstation (Zahner Co., Ltd.) with the THALES 3.08 software package. The samples were the working electrode and the $\mathrm{Ag} / \mathrm{AgCl}$ couple for each potential was used for the reference electrode. Spectrally pure $\mathrm{Pt}$ wire served as counter-electrode.

Among the numerous methods of study of electrochemical corrosion, polarization is one of the largest used. This method consists of performing electrolysis that is used as electrode and electrolyte, respectively the metal and medium whose interaction under study. The test may be conducted at controlled electrode potential (by measuring the function of current values the applied potential), or the electrolysis current controlled (potential values as a function of current). The plotting upwards after plotting $E=f(i)$ or $I=f(E)$ gives the polarization curve [23].

\section{Calculation of corrosion rate}

In oxidizing environment on the surface of steels with low carbon and high chromium content (least $12 \%$ chromium) an invisible passive film with $2-4 \mathrm{~nm}$ thickness is formed, which make these steels corrosion resistant. This film is capable to rebuild by oxidizing the underlying metal when the surface has been damaged. There are environments in which the passive layer is permanently or locally degraded, causing corrosion of the unprotected surface. Different substrates can cause different types of corrosion attacks, which may vary in nature and appearance. Uniform or general corrosion occurs at a uniform rate of corrosion on the surface exposed to the entire corrosion medium (often an aggressive acid such as hydrochloric acid or hydrogen fluoride). Corrosion rate is usually expressed as material loss in mm / year and can thus be used to estimate service life.

Faraday's Law can be used to calculate the corrosion rate, either in terms of penetration rate (CR) or mass loss rate (MR) [24]. The corrosion rate (CR), given in mm/year can be calculated from current $\operatorname{density}\left(i_{\text {corr }}\right)$, equivalent weight of alloy $(\mathrm{EW})$ and material density $(\rho)$

$$
C R=K_{1} \frac{i \text { corr }}{\rho} E W
$$

where

$\mathrm{K}_{1}=3.27 \cdot 310^{-3}, \mathrm{~mm} \mathrm{~g} / \mu \mathrm{A} \mathrm{cm}$ year,

$\rho=$ density, $\mathrm{g} / \mathrm{cm}^{3}$

$i_{\text {corr- }}$ corrosion current density, $\mu \mathrm{A} / \mathrm{cm}^{2}$

$E W$ - equivalent weight of the alloy, considered dimensionless

$\mathrm{CR}$ is given in $\mathrm{mm} / \mathrm{year}$

The corrosion density is the total corrosion current per unit area

where:

$$
i_{\text {corr }}=\frac{I_{\text {corr }}}{A}
$$

$I_{\text {corr- }}$ total anodic current, $\mu \mathrm{A}$,

$A$ - exposed specimen area, $\mathrm{cm}^{2}$.

Corrosion current values may be obtained from galvanic cells and polarization measurements, including Tafel extrapolations or polarization resistance measurements.

The equivalent weight of the alloy depends on mass fraction, atomic weight and valence of alloy components

$$
E W=\sum \frac{W_{i}}{n_{i} \cdot f_{i}}
$$


where:

$W_{i}$ - the atomic weight of the $i^{\text {th }}$ element in the alloy,

$f_{i}$ - is the mass fraction of the $i^{\text {th }}$ element in the alloy,

$n_{i}$ - the valence of the $i^{\text {th }}$ element of the alloy.

For the mass loss rate (MR):

where:

$$
\mathrm{MR}=\mathrm{K}_{2} \mathrm{i}_{\text {corr }} \mathrm{EW}
$$

$$
\begin{aligned}
& \mathrm{MR}=\mathrm{g} / \mathrm{m}^{2} \mathrm{~d} \\
& \mathrm{~K}_{2}=8.954 \cdot 10^{-3}, \mathrm{~g} \mathrm{~cm}^{2} / \mu \mathrm{A} \mathrm{m}{ }^{2} \mathrm{~d} .
\end{aligned}
$$

\section{Results and discussions}

The microstructure of TIG welded steels differ from the microstructure of laser beam welded materials not only by the shape and area of weld metals, but in case of duplex stainless steels the ferrite/austenite ratio modifies also with welding speed. The ratio of the weld depth to width increase with welding speed Etching with Beraha'2 reagent the light austenitic phase is well distinguishable from ferrite in micrographs. (Figure 2-Figure 4)). The ferritic content at duplex stainless steels in weld metal and HAZ increase during to welding. Increasing the welding speed the ferrite content in weld metal increase (Figure 3-4). For this reason the corrosion resistance modify also.
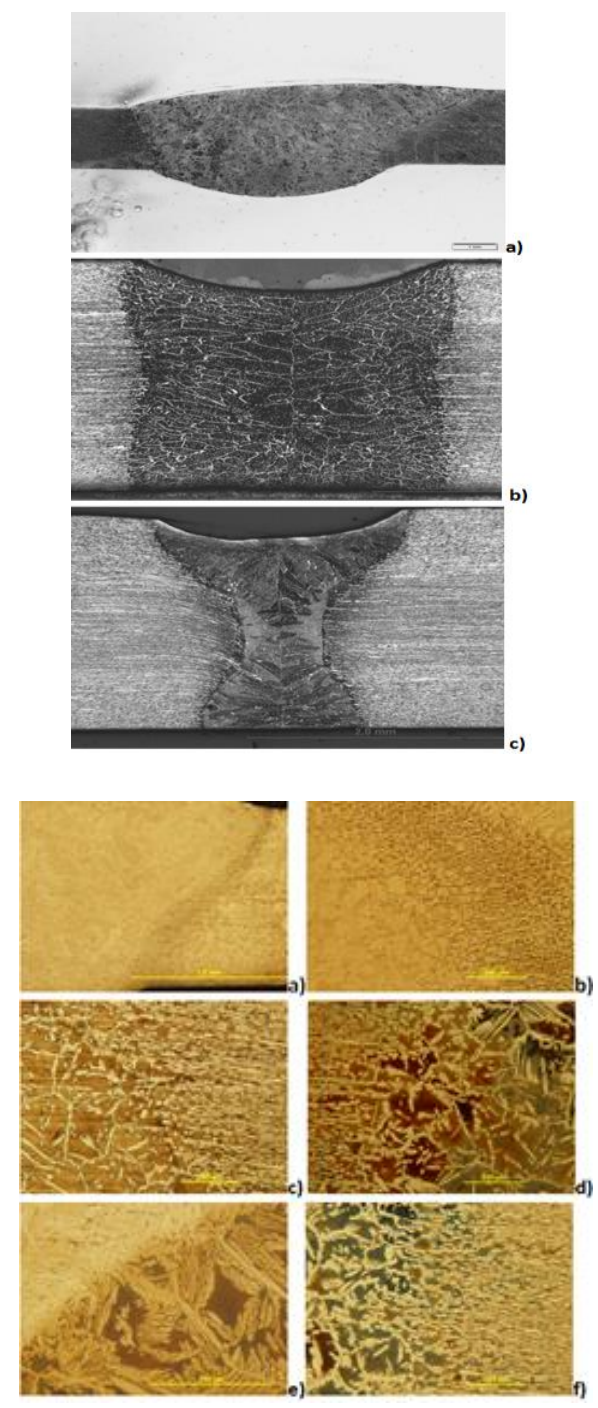

Rev. Chim., 71 (3), 2020,440-449
Figure 2. The macrostructure of weld metals after different method of welding a) heterogenous TIG welding of 304ausztenitic- 2404 duplex steel

$$
\begin{gathered}
\mathrm{N}_{\text {orig }}=8 \mathrm{x} \text { b) } \mathrm{v} \text { laser }=750 \mathrm{~mm} / \mathrm{min} \\
\left.\mathrm{N}_{\text {orig }}=25 \mathrm{x} \mathrm{c}\right) \mathrm{v}_{\text {laser }}=1500 \mathrm{~mm} / \mathrm{min}, \\
\mathrm{N}_{\text {orig }}=25 \mathrm{x} \text { Beraha reagent }
\end{gathered}
$$

Figure 3. Microstructire of TIG welded samples a) Weld metal HAZ shape at 304 steel

$\mathrm{N}_{\text {orig }}=25 \mathrm{x}$ b) HAZ at 304 steel $\mathrm{N}_{\text {orig }}=100 \mathrm{x}$

c)HAZ at 2304 steel

d) HAZ at 2404 steel e) heterogenous welding near 304 steel f) heterogenous welding near 2404 duplex steel steel 


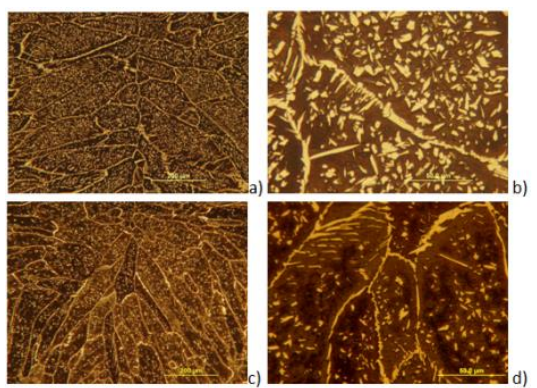

Figure 4. The weld metal microstructure at 2304 steel after autogenous laser beam welding. Beraha' reagent

a) $\mathrm{v}_{\text {laser }}=750 \mathrm{~mm} / \mathrm{min} \mathrm{N}_{\text {orig }}=100 \mathrm{x}$;

b) $\mathrm{v}_{\text {laser }}=750 \mathrm{~mm} / \mathrm{min} \quad \mathrm{N}_{\text {orig }}=500 \mathrm{x}$

c) $\mathrm{v}_{\text {laser }}=1500 \mathrm{~mm} / \mathrm{min} \mathrm{N}_{\text {orig }}=100 \mathrm{x}$

e) $\mathrm{v}_{\text {lase }}=1500 \mathrm{~mm} / \mathrm{min} \mathrm{N}_{\text {orig }}=500 \mathrm{x}$

Even if the chemical composition of autogenously laser welded materials do not changes in comparisons with parent materials, the microstructural modifications can modify the corrosion resistance.

To study the corrosion resistance in electrochemical conditions of welded couples the metallographic prepared surfaces near weld metals were painted by lacquer around but the welded contacts were immersed into the electrolytic solution.

Comparing the Tafel curves for TIG welded samples (Figure 5) and laser beam welded samples (Figure 6) taken in $5 \mathrm{mV}$ of rate some difference can be observed between them. In case of TIG welding the most negative corrosion potential belong to sample 2404 and the heterogenous sample (304 -2404) has the lowest corrosion current density and highest corrosion potential.

In case of laser beam welding the joints of austenitic and 2404 steel have similar corrosion properties, even if the joint was homogenous or heterogenous. The highest corrosion potential has the lean duplex 2304 seam, which can refer to its lowest corrosion resistance. This study presents a good correspondence with pitting corrosion results.

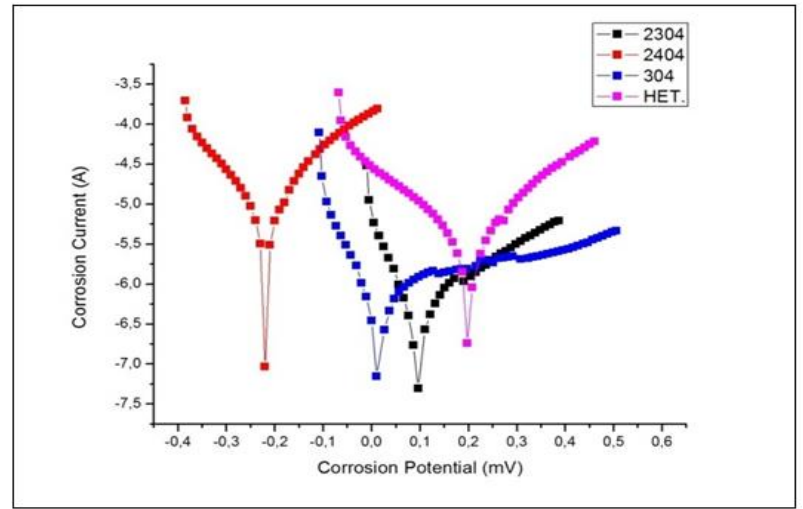

Figure 5. Tafel curve for TIG welded samples, $5 \mathrm{mV}$ of rate

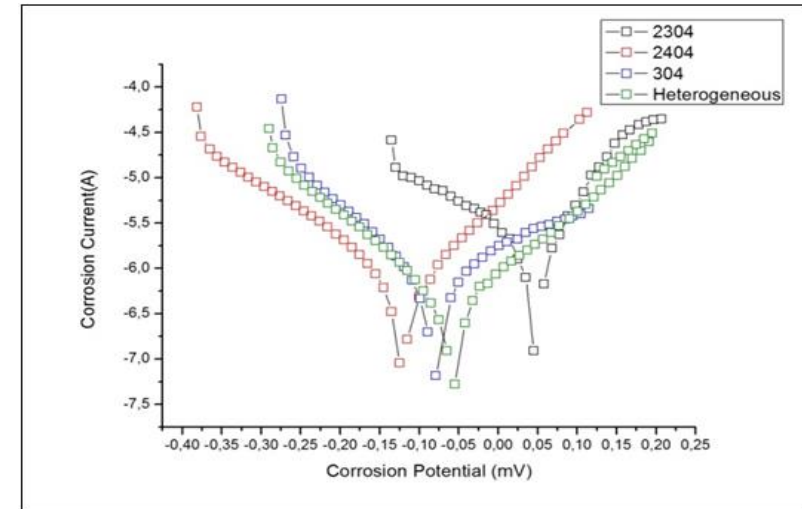

Figure 6. Tafel curve for laser beam welded samples in a $5200 \mathrm{~W}$ of power and $5 \mathrm{mV}$ of rate

To study of pitting corrosion resistance samples with $10 \mathrm{~mm}$ x $25 \mathrm{~mm}$ sizes were cut. Before the study the coloured, oxidized surfaces near the seams were pickled and ultrasonic cleaned in ethanol. After draying the samples were put separately into glasses containing aqueous ferric chloride with $6 \%$ density, conform ASTM G48. Studying the corrosion behaviour of the welded joints it was observed that in case of TIG welded steels, the pitting corrosion are concentrated in HAZ (Figure 7.). 


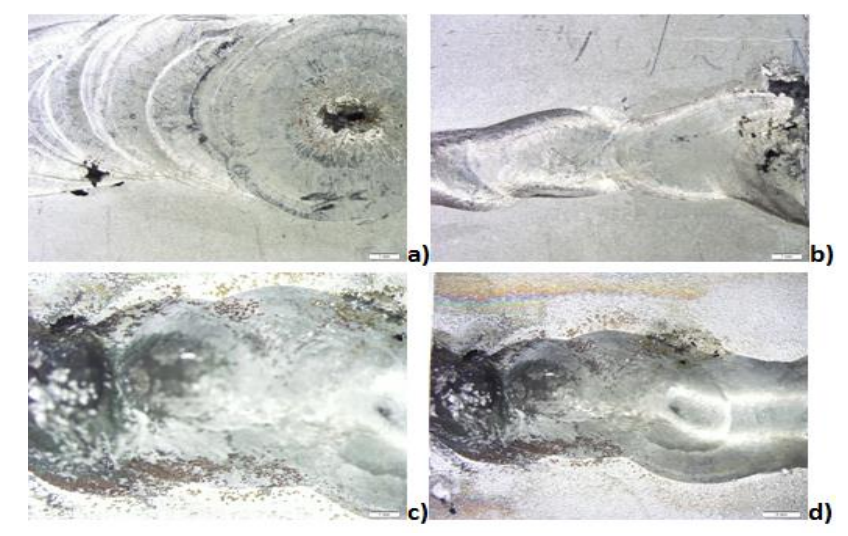

Figure 7. Stereomicrographs after pitting corrosion test at TIG welded steels: a) VM face at 304 steel b) root at 304 steel, c) VM face at 2304 steel d) root at 2304 steel

In case of laser welded duplex stainless steels, pitting appeared on heat affected zones and on the seam surfaces (Figure 8). In case of austenitic stainless-steel pitting corrosion appear as in parent materials as in welding zones (Figure 9).

Increasing the welding power in case of laser beam welding of duplex stainless steels the pitting resistance increase, but in the case of austenitic and heterogenous welding appear contradictions (Table 3), which can be explaned with the character of pitting corrosion (Table 3, Figure 8-10)
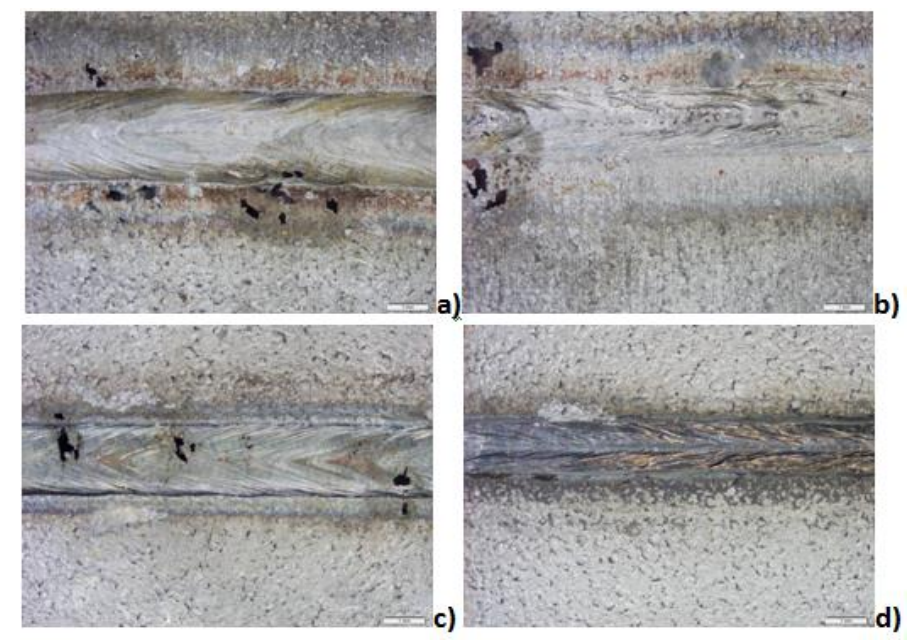

Figure 8. Stereomicrographs after pitting corrosion test at autogenous laser beam welded 2304 duplex stainless steel:

a) $\mathrm{VM}$ face $\mathrm{V}$ laser $=750 \mathrm{~mm} / \mathrm{min}$ b) $\mathrm{VM}$ root $\mathrm{v}$ laser $=750 \mathrm{~mm} / \mathrm{min}$

c) $\mathrm{VM}$ face $\mathrm{v}$ laser $=1800 \mathrm{~mm} / \mathrm{min} \mathrm{d}$ ) root at $\mathrm{v}$ laser $=1800 \mathrm{~mm} / \mathrm{min}$

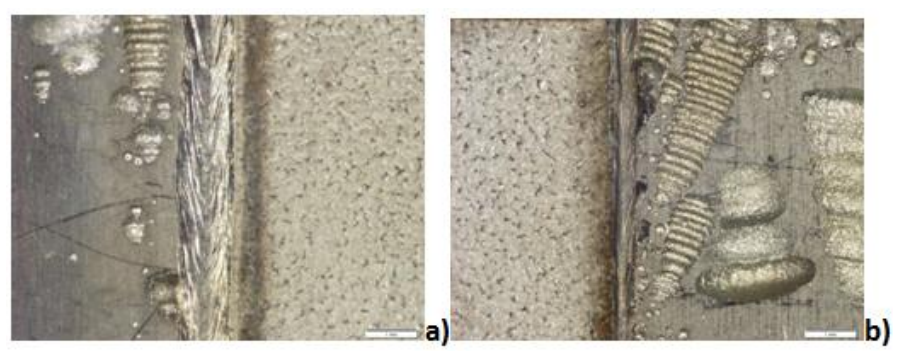

Figure 9. Stereomicrographs after pitting corrosion test at heterogenous welded sample a) face b) root 

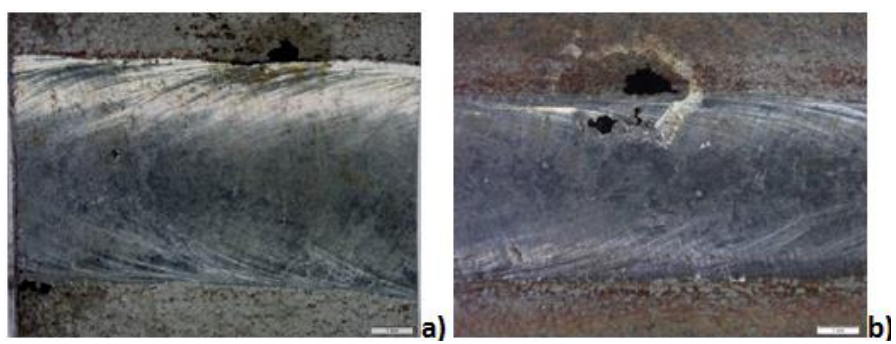

Figure 10. Micrographs after pitting corrosion test at 2304 laser beam welded steel with wire addition

a) $\mathrm{v}_{\text {laser }}=350 \mathrm{~mm} / \mathrm{min} \mathrm{v}_{\text {wire }}=1000 \mathrm{~m} / \mathrm{min}$

b) $\mathrm{v}_{\text {laser }}=500 \mathrm{~mm} / \mathrm{min} \mathrm{v}_{\text {wire }}=1000 \mathrm{~m} / \mathrm{min}$

Table 3. Mass loss after $72 \mathrm{~h}$ pitting corrosion at autogenously laser beam welded samples

\begin{tabular}{|c|c|c|c|}
\hline $\begin{array}{c}\text { Laser welded } \\
\text { sample }\end{array}$ & $\begin{array}{c}\text { Parent } \\
\text { material }\end{array}$ & P[W] & $\begin{array}{c}\text { Mass loss } \\
\left(\mathbf{g} / \mathbf{c m}^{2}\right)\end{array}$ \\
\hline L1 & 2304 & 5200 & 0,13475 \\
\hline L2 & 2304 & 3800 & 0,14130 \\
\hline L3 & 2304 & 2000 & 0,15005 \\
\hline L4 & 2404 & 5200 & 0,04055 \\
\hline L5 & 2404 & 3800 & 0,04195 \\
\hline L6 & 2404 & 2000 & 0,06475 \\
\hline L7 & 304 & 5200 & 0,08175 \\
\hline L8 & 304 & 3800 & 0,06160 \\
\hline L9 & 304 & 2000 & 0,09190 \\
\hline L10 & $2404-304$ & 5200 & 0,09410 \\
\hline L11 & $2404-304$ & 3800 & 0,10615 \\
\hline L12 & $2404-304$ & 2000 & 0,09775 \\
\hline
\end{tabular}

Aplying additional material during to laser beam welding has beneficial effect on corrosion resistance (Figure 8-11)

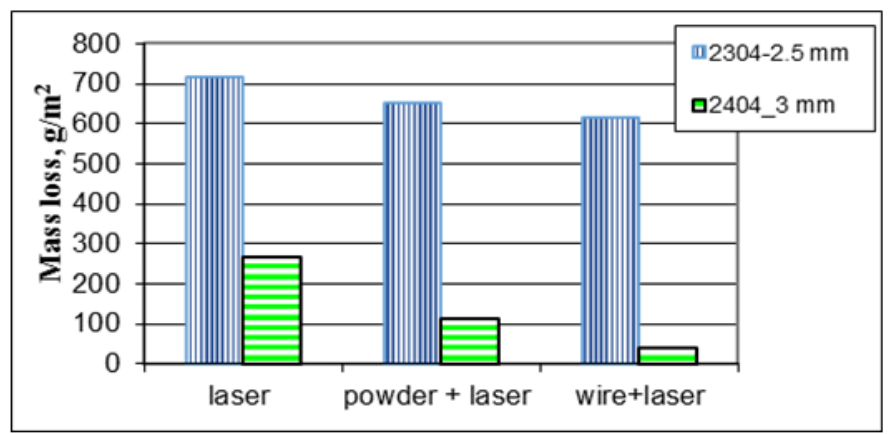

Figure 11. The additional materials effect on corrosion resistance

Appling additional materials during laser welding the pitting resistance increase, pitting apparence were concentrated in heat affected zone

\section{Conclusions}

Increasing welding speed decreased corrosion rate of welded joints that means with the decrease in heat input. At austenitic stainless-steel pitting corrosions appeared in base metal as well as in welding zone. In case of 2304 duplex stainless steel pitting corrosion appeared in weld metal and heat affected zone in case of autogenously welding, but at 2404 duplex stainless steel pitting appear more in heat 
affected zone. It was observed applying welding wire during to laser welding the mass loss can be reduced.

In case of laser beam welding the joints of 2404 duplex steel sheets and 304, austenitic steel sheets have similar corrosion properties, even if the joint was homogenous or heterogenous. The lowest corrosion resistance has the lean duplex 2304 steel seam.

In case of TIG welding the most negative corrosion potential has the weld metal at 2404 duplex steel sample and the dissimilar welded joint (304 - 2404) has the lowest corrosion current density and highest corrosion potential.

Acknowledgements. The authors thank for the financial support given by the project EFOP-3.6.1-162016-00010.

\section{References}

1.PAGOTTO, J.F., Métodos de Proteção contra a Corrosão de ligas metálicas. PhD Thesis, 2013 2.***Standard Cr-Ni Stainless Steels. Outokumpu Stainless AB, Avesta Research Centre Box 74, SE77422 Avesta, Sweden. p.3.

3.JONES, D.A., Principles and prevention of corrosion, New York, McMillan, 1992.

5.Elivelton A. FERREIRA, Raone C. De C. SILVA, Larissa A. T. COSTA, Caroline P. R. de OLIVEIRA, Gilmar C. SILVA, Andersan dos S. PAULA, Cecílio S. FUGIVARA, Assis V. BENEDETTI Corrosion Engineering, Science and Technology, 53:7, 2018, pp 502-509,

4.BALTATU, M.S., VIZUREANU, P., CIMPOESU, R., ABDULLAH, M.M.A., SANDU, A.V., Rev. Chim., 67(10), 2016, 2100.

5.S TOPOLSKA. IOP Conf. Ser.: Mater. Sci. Eng.145, 2016. 072014.

6.BALTATU, M.S., VIZUREANU, P., CIMPOESU, R., ABDULLAH, M.M.A., SANDU, A.V., Rev. Chim., 67(10), 2016, 2100

7.BURDUHOS-NERGIS, D.P., NEJNERU, C., BURDUHOS-NERGIS, D.D., SAVIN, C., SANDU, A.V., TOMA, S.L., BEJINARIU, C., Rev. Chim., 70(1), 2019, 215

8.BALTATU, M.S., TUGUI, C.A., PERJU, M.C., BENCHEA, M., SPATARU, M.C., SANDU, A.V., VIZUREANU, P., Rev. Chim., 70(4), 2019, 1302.

9.SANDU, A.V., BALTATU, M.S., NABIALEK, M., SAVIN, A., VIZUREANU, P., MATERIALS, 12, no. 18, 2019, Article Number: 2973

10.MINCIUNA, M.G., VIZUREANU, P., ACHITEI, D.C., GHIBAN, B., SANDU, A.V., MARECI, D., BALAN, A., Rev. Chim., 65(10), 2014, 1138.

11.BALTATU, S., VIZUREANU, P., MARECI, D., BURTAN, L.C., CHIRUTA, C., TRINCA, L.C., Materials And Corrosion-Werkstoffe Und Korrosion, 67, no. 12, 2016, p. 1314.

12.SANDU, A.V., CIOMAGA, A., NEMTOI, G., ABDULLAH, M.M.A., SANDU, I., INSTRUMENTATION SCIENCE \& TECHNOLOGY, 43, 5, 2015, pp. 545.

13.VIZUREANU, P., Metalurgia International, 14, no. 5, 2009, p. 5.

14.VIZUREANU, P., PERJU, M.C., GALUSCA, D.G., NEJNERU, C.,AGOP, M., Metalurgia International, 15, no. 12, 2010, p. 59.

15.GUNN, R.N., Duplex stainless steels. Abington Publishing, Cambridge, p: 1-47, 110-143,1999.

16.NILSSON, J., Super duplex stainless steels. Materials Science and Technology, Vol.8., 1992, p. 685 .

17.NILSSON, J., KANGAS, P., KARLSSON, T., WILSON, A., Metallurgical and Materials Transactions A. 31, 2000, p. 35.

18.KARLSSON, L., RYEN, L., PAK. S., Welding Journal, 74, 1995, p.28.

19.LILJAS, M., The welding metallurgy of duplex stainless steels, Proceedings of 4th International Conference on DSS, 2, 1994, p. 1.

20.OKANO, S., TSUJI, H., MOCHIZUKI, M., Sci. Technol. Weld. Join. 22, 2017, p. 59. 
21.***Duplex Stainless Steel. Outokumpu Stainless AB, Avesta Research Centre Box 74, SE-774 22 Avesta, Sweden.

22.***Estimativa de gastos com corrosão em países desenvolvidos. Institute of Corrosion, Northampinton, 2013, Available in www.icorr.org

23.MELLO, L., Estudo de corrosao localizada dos aços inoxidáveis em sistemas de resfriamento industrial, Rio de Janeiro, UFRJ.Escola Politecnica, 2011.

24.MA, F Y Corrosive Effects of Chlorides on Metals, Pitting Corrosion, Nasr Bensalah, ISBN: 978953-51-0275-5Intech Open,2012

25.***Potentiodynamic Polarization Measurements. Princeton Applied Research, 801 S. Illinois Avenue, Oak Ridge, TN 37830. Available from: www.princetonappliedresearch.com

26.***Standard Practice for Calculation of Corrosion Rates and Related Information from Electrochemical Measurements. ASTM Designation: G 102 - 89 (Reapproved 1999)

$\overline{\text { Manuscript received: } 28.02 .2020}$ 